\title{
Analysis of Acetyl Co-A Carboxylase Activity in Marine Diatoms Isolated from Vellar Estuary, Southeast Coast of India
}

\author{
Shailesh Upadhyay ${ }^{1 *}$, Kapil Lawrence ${ }^{1}$, Sudhir K. Shekhar ${ }^{2}$, \\ M. Suresh ${ }^{3}$ and P. Anantharaman ${ }^{3}$
}

${ }^{1}$ Department of Biochemistry and Biochemical Engineering, JIBB, Sam Higginbottom University of Agriculture, Technology and Sciences (SHUATS) (formerly Allahabad Agricultural Institute) Allahabad, 211007 India

${ }^{2}$ Department of Biotechnology, Babasaheb Bhimrao Ambedkar University (A Central University), Lucknow, India

${ }^{3} \mathrm{CAS}$ in Marine Biology, Annamalai University, Parangipettai, Tamilnadu, India

*Corresponding author

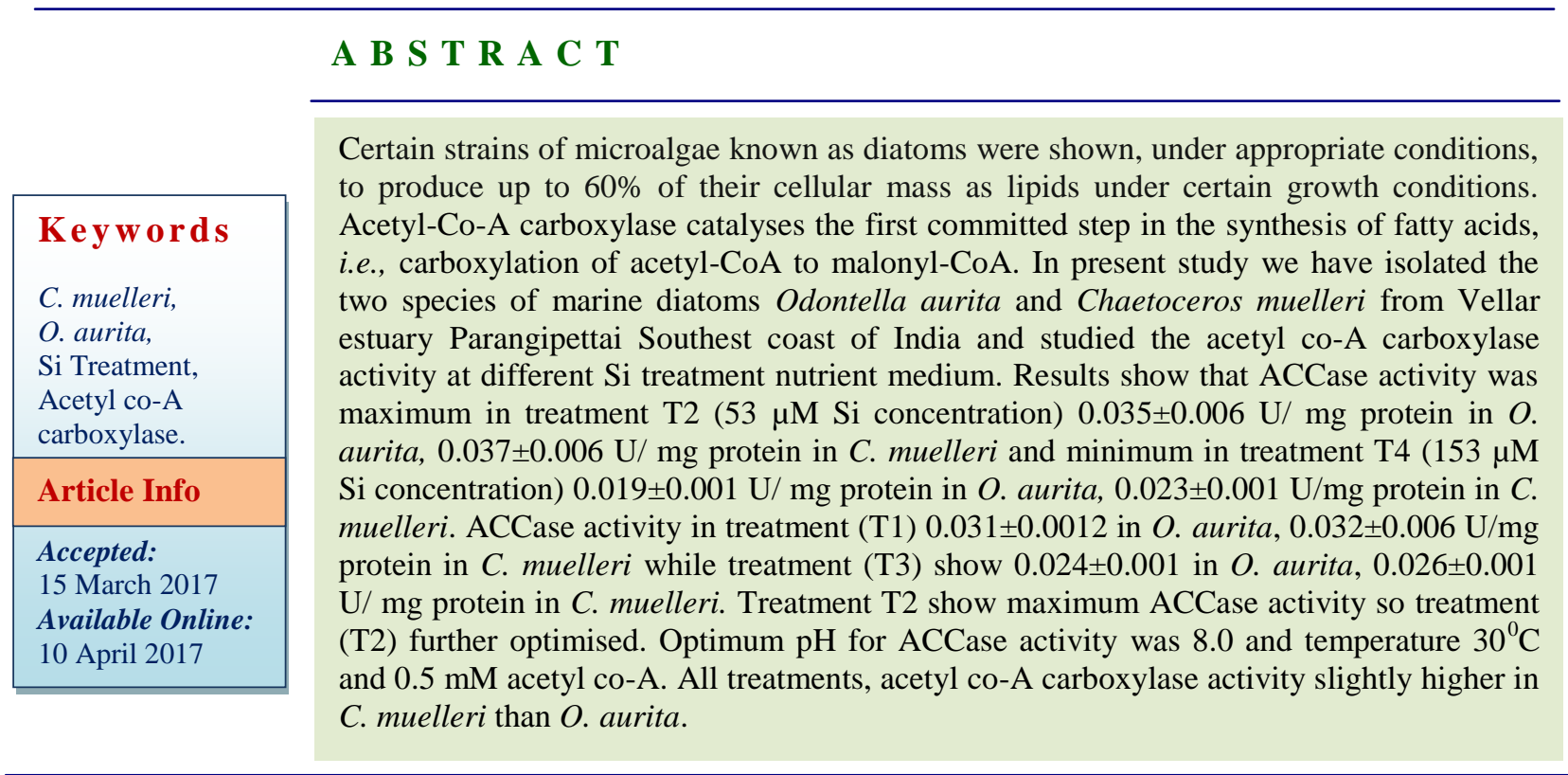

\section{Introduction}

Global warming and shortage of energy are two critical issues to human social development in the 21st century. Worldwide shortage of fossil fuels is an urgent problem. It enforces scientists to accelerate the search for alternative fuels (Vicente et al., 2004).The bio-fuel production from photosynthetic microorganisms is considered as a process to produce renewable energy for global warming mitigation (Palanisami et al., 2013). In recent times microalgae have received much attention as a renewable energy resource (Hsieh and $\mathrm{Wu}, 2009$ ). Certain strains of microalgae known as diatoms were shown, under appropriate conditions, to produce up to $60 \%$ of their cellular mass as lipids under 
certain growth conditions. These lipids can be easily converted into biodiesel through a transesterification reaction (Yu et al., 2009).

Intensive research is currently focused on characterizing and controlling the biosynthesis and accumulation of high-value storage products such as lipid and polyunsaturated fatty acids (Work et al., 2010; Msanne et al., 2012). However, current knowledge regarding the regulation of carbon flow within cells and mainly in plastids is significantly lacking. Numerous attempts to manipulate and control the tunnelling of carbon have been conducted in recent years, most of which are attempts to increase carbohydrates and lipid contents in oleaginous species through the expression or down regulation of various plastid-localized ratelimiting enzymes, such as acetyl coenzyme -A carboxylase (ACCase). However, these attempts were mostly unsuccessful, probably due to the deprived understanding of plastid regulatory mechanisms that control carbon flow in microalgae (Lardizabal et al., 2008; Li et al., 2010; Andre et al., 2012). It is generally accepted that the main precursor for de novo fatty acid biosynthesis in photosynthetic species is acetyl coenzyme A, its production capacity has been largely ignored whereas its conversion to malonylCoA through the plastidic ACCase was widely accepted as a major bottleneck for fatty acids and lipid biosynthesis (Klaus et al., 2004; Sasaki and Nagano, 2004; Huerlimann and Heimann, 2013).

There is a broad range of variability in lipid yields between species, as well as a fair amount of strain-to-strain variation within the same species (Yu et al., 2009). Although lipids are formed under a variety of environmental stress conditions, there have not been systematic comparisons of the yield and molecular makeup of lipid produced under these different conditions in the same species (Mock et al., 2008). Nitrate starvation likely has a different impact on metabolic activity than silicate limitation. For example, previous work has shown that de novo protein synthesis is required for starvation-induced increase in acetyl CoA carboxlase (ACCase) activity in the diatom Cyclotella cryptica (Roessler, 1988). If the protein synthesis required to create enzymes for lipid formation is impacted by nitrate limitation, then there is a possibility that induction by nitrate starvation could result in a different pattern of lipid formation than that found under silicate starvation (Roessler, 1988).

The biochemical mechanism that underline the procedure of lipid accumulation have never been elucidated. The relative importance of altered partitioning of recently assimilated carbon and redistribution of earlier assimilated carbon from non-lipid compound into lipids in the lipid accumulation procedure has not been strongly established (Ben-Amtoz et al., 1985; Suen et al., 1987). The nature of lipid produced by silicon deficient diatoms has not been reported (Roessler, 1988), The research described in this paper represents intial efforts towards a determine the enzyme acetyl co-A carboxylase activity in marine diatoms Odontella aurita and Chaetoceros muelleri cultivated in different $\mathrm{Si}$ treatment nutrient medium to understanding the biochemistry of ACCase activity in different $\mathrm{Si}$ treatment diatoms.

\section{Materials and Methods}

\section{Isolation and Identification of marine diatom}

The marine diatom, Odontella aurita was collected from Vellar estuary, Parangipettai, Tamilnadu, Southeast coast of India (Bay of Bengal) with the Latitude $11^{\circ} 29^{\prime} \mathrm{N}$ and Longitude $79^{\circ} 46^{\prime} \mathrm{E}$. The diatom collection 
was done by horizontal towing of phytoplankton net (No-30, bolting silk cloth, $45 \mu \mathrm{m}$ ) during early morning by following the method of Mohan et al., (2012). The individual diatom strain was isolated using serial dilution. Then the isolated pure cultures were maintained in Guilard, f/2 (1975) medium.

The diatom was examined under a zoom stereomicroscope (Olympus). The diatom was identified according to their morphological characteristics with help of standard taxonomic references as previously described by Thomas (1997), Venkataraman (1939) and Subrahmanyan (1946).

\section{Cultivation of diatom at different $\mathrm{Si}$ treatment}

The isolated diatom was cultivated in different Si treatment Guilard, f/2 (1975) medium. All the experiments were conducted in 5 litre conical flasks. The culture was provided with 12:12 dark: light cycle with 4500 lux white fluorescent lamp at temperature $25^{\circ} \mathrm{C} \pm 2{ }^{\circ} \mathrm{C}$.

In this study four $\mathrm{Si}$ treatments were evaluated, treatment 1(T1) consisted of the standard f/2 medium without $\mathrm{Si}(0 \mu \mathrm{M} \mathrm{Si}), \mathrm{T} 2$ consisted $\mathrm{f} / 2$ medium with reduced $\mathrm{Si}(53 \mu \mathrm{M}$ $\mathrm{Si}$ ), T3 consisted f/2 medium (Si $106 \mu \mathrm{M})$, T4 consisted f/2 medium with increased Si (159 $\mu \mathrm{M} \mathrm{Si}$ ), T3 treated as control, all treatments taken in triplicate. All data show in mean value.

\section{Crude Enzyme Extraction}

Crude enzyme extract was prepared by method given by Dayan et al., (2015) slightly modified. Brifelly fresh harvested biomass of both species of diatoms were grinded in liquid nitrogen and sterile-washed sea sand in a mortar and pestle with $5 \mathrm{ml}$ extraction buffer
$50 \mathrm{mM}$ Tris $\mathrm{pH} \quad 8.0,1 \mathrm{mM}$ EDTA, $10 \%$ glycerol, $2 \mathrm{mM}$ L-ascorbic acid, $1 \mathrm{mM}$ phenylmethanesulfonyl fluoride (PMSF), $20 \mathrm{mM} \quad$ dithiothreitol, $0.5 \%$ polyvinylpyrrolidone $\quad 40, \quad 0.5 \%$ polyvinylpolypyrolidone (PVPP). Filter the extract through four layers of cheesecloth into a centrifuge tube and further centrifuged at $4^{0} \mathrm{C}$ for $20 \mathrm{~min}$ at $25000 \mathrm{X} \mathrm{g}$. The protein concentration was determined by Lowry method (Lowry et al., 1951).

\section{AC Case Assay}

ACCase activity was measured by method following by Evenson et al., (1994) slightly modified. Briefly, ACCase activity was measured by coupling the production of ADP to the oxidation of NADH by PK and LDH (Rendina et al., 1988). The reaction was measured by following the change in Absorbance at $340 \mathrm{~nm}$ for $3 \mathrm{~min}$ at $30^{\circ} \mathrm{C}$.

The standard reaction mixture contained 50 $\mathrm{mM}$ Tris- $\mathrm{HCl}, \mathrm{pH} 8.0,0.4 \mathrm{M}$ glycerol, $50 \mathrm{mM}$ KCI, $0.5 \mathrm{mM}$ DTT, $2.5 \mathrm{mM}$ ATP, $5 \mathrm{mM}$ $\mathrm{MgS04}, \quad 0.5 \mathrm{mM}$ acetyl-CoA, $15 \mathrm{mM}$ $\mathrm{NaHCO}_{3}, 0.32 \mathrm{mM}$ NADH, $0.5 \mathrm{mM}$ PEP, 1.25 units of PK, 1.5 units of $\mathrm{LDH}$, and and 0.20 $\mathrm{mL}$ of crude enzyme eextract in a final volume of $3.0 \mathrm{~mL}$. Acetyl-CoA was then added to initiate the reaction, which was allowed to proceed for $3 \mathrm{~min}$. One unit of enzyme activity is defined as the amount of enzyme that catalyzes the carboxylation of 1 $\mu$ mol acetyl- CoA min $^{-1}$ under the conditions described above, treatment which show maximum ACCase activity further optimised, Optimum $\mathrm{pH}$, temperature and acetyl co-A.

\section{Results and Discussion}

Marine diatom was isolated from the Vellar estuary Southeast coast of India and identified as $O$. aurita and Chaetoceros muelleri by morphologically. O. aurita and Chaetoceros 
muelleri were cultivated in different $\mathrm{Si}$ concentration (T1, T2, T3 and T4 Treatment) Guilard, f/2 (1975) medium. Microscopic structure and morphology of $O$. aurita and Chaetoceros muelleri was observed by light microscope shown in figures 1 and 2. The cells of Odontella aurita under the light microscope were solitary with four auriculate projections and occasionally formed chains. The cells were found to have numerous chloroplasts lying along the cell wall (Figure 1). Cells of Chaetoceros muelleri are similar to Chaetoceros calcitrans with rectangular shape in girdle view and elliptical shape in valve view. Strain is slightly larger (between 10 and $15 \mu \mathrm{m}$ ), setae are longer and straighter (Figure 2).

\section{Acetyl co-A carboxylase activity at different treatment}

Acetyl co-A carboxylase activity in crude extract of $O$. aurita and $C$. muelleri at different $\mathrm{Si}$ treatment shown in figure 3. Maximum enzyme activity observed in treatment $\mathrm{T} 2$ ( $\mathrm{Si}$ concentration $53 \mu \mathrm{M}$ ) in both species, $0.035 \pm 0.006,0.037 \pm 0.006 \mathrm{U} / \mathrm{mg}$ protein in $O$. aurita and $C$. muelleri respectively. Treatment $\mathrm{T} 4$ ( $\mathrm{Si}$ concentration $159 \mu \mathrm{M})$ show minimum activity $0.019 \pm 0.001$ in $O$. aurita, $0.023 \pm 0.001 \mathrm{U} / \mathrm{mg}$ protein in $C$. muelleri, treatment $\mathrm{T} 1$ show more activity than treatment $\mathrm{T} 3$ and $\mathrm{T} 4$ but less than Treatment T2. Treatment T1 showed activity $0.031 \pm 0.0012$ in $O$. aurita $0.032 \pm 0.006 \mathrm{U} / \mathrm{mg}$ protein in $C$. muelleri. Acetyl co-A carboxylase observed slightly higher activity in $C$. muelleri than $O$. aurita in all Si treatment.

Treatment T2 (Si concentration $53 \mu \mathrm{M}$ ) show maximum acetyl co-A carboxylase activity in both species so that treatment taken to further study of optimization of enzyme such as $\mathrm{pH}$, temperature and acetyl co-A.

\section{Effect of acetyl co-A}

Figure 4 shows the acetyl co- A carboxylase activity at different concentration of acetyl co-A. Figure 4 shows that as acetyl co-A concentration increases $(0.1 \mathrm{mM}-0.9 \mathrm{mM})$ enzyme activity increases, at concentration $0.5 \mathrm{mM}$ acetyl co-A enzyme activity achieved maximum activity $0.0068 \pm 0.001$ and $0.038 \pm 0.0015 \mathrm{U} / \mathrm{mg}$ protein in $O$. aurita and C. muelleri respectively. After $0.5 \mathrm{mM}$ acetyl co-A ACCase activity constant in both species. Minimum enzyme activity observed at $0.1 \mathrm{mM}$ acetyl co-A, where $0.0068 \pm 0.001$ $\mathrm{U} / \mathrm{mg}$ protein in O. aurita and $0.0084 \pm 0.0018$ $\mathrm{U} / \mathrm{mg}$ protein in $C$. muelleri.

\section{Effect of $\mathbf{p H}$}

Figure 5 shows the acetyl co $-\mathrm{A}$ carboxylase activity at different $\mathrm{pH}$ ( $\mathrm{pH}$ 6.0-10.0). ACCase activity $\mathrm{pH} 6.0$ to $\mathrm{pH} 8.0$ rapidly increases, at $\mathrm{pH} 10.0$ sharply down. Maximum enzyme activity at $\mathrm{pH}$ 8.0, $0.036 \pm 0.0035$ in $O$. aurita and $0.038 \pm 0.001$ $\mathrm{U} / \mathrm{mg}$ protein in C. muelleri. At $\mathrm{pH} 7.0$ and pH 9.0 acetyl co-A carboxylase activity slightly decreases, minimum activity observed at $\mathrm{pH} 6.0,0.012 \pm 0.001$ in $O$. aurita and $0.013 \pm 0.002 \mathrm{U} / \mathrm{mg}$ protein in $C$. muelleri.

\section{Effect of temperature}

Figure 6 shows that acetyl co $-\mathrm{A}$ carboxylase activity at different temperature $\left(20^{\circ} \mathrm{C}-40^{\circ} \mathrm{C}\right)$. Figure shows that maximum enzyme activity at $30^{\circ} \mathrm{C}, 0.036 \pm 0.0035$ in $O$. aurita and $0.038 \pm 0.0015 \mathrm{U} / \mathrm{mg}$ protein in $C$. muelleri. As temperature increases, enzyme activity also increases, at $40^{\circ} \mathrm{C}$ enzyme activity decreases sharply. Minimum enzyme activity observed at $20^{\circ} \mathrm{C}, 0.0075 \pm 0.0006 \mathrm{U} / \mathrm{mg}$ protein in $O$. aurita and $0.011 \pm 0.0007$ $0.0075 \pm 0.0006 \mathrm{U} / \mathrm{mg}$ protein in $C$. muelleri. 


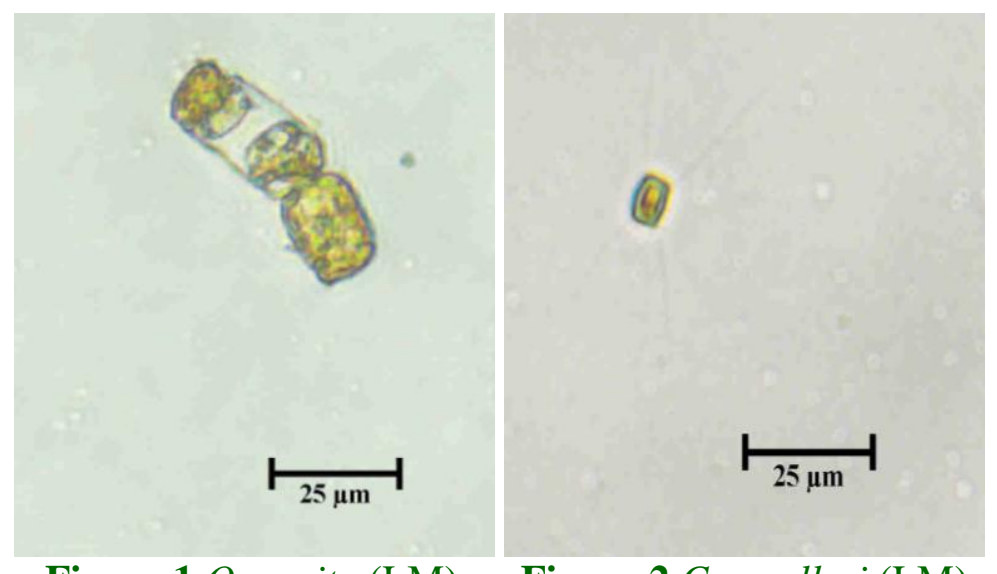

Figure.1 O. aurita (LM) Figure.2 C. muelleri (LM)

Acetyl-CoA carboxylase catalyses carboxylation of acetyl-CoA to malonyl-CoA. It is believed that acetyl-CoA carboxylase may be the rate-limiting step in the biosynthesis of fatty acids and any change in the activity of acetyl- CoA carboxylase may affect lipid biosynthesis (Ahmad et al., 2000; Madoka et al., 2002). ACCases from algae and the majority of ACCases from higher plants are similar, responsible for both biotin carboxylation and subsequent carboxyl transfer to acetyl CoA (Roessler, 1990).

Present study show that maximum acetyl coA carboxylase activity in treatment $\mathrm{T} 2$ and $\mathrm{T} 1$, Si stress condition (T1 and T2 ) show higher activity than T3 and T4 treatment (Si rich medium). Roessler (1988) investigated changes in the activities of various lipid biosynthetic enzymes in the diatom Cyclotella cryptica in response to silicon deficiency. The activity of ACCase increased approximately two- and fourfold of silicon-deficient growth, respectively, suggesting that the higher ACCase activity may partially result from a covalent modification of the enzyme. As the increase in enzymatic activity can be blocked by the addition of protein synthesis inhibitors, it was suggested that the enhanced ACCase activity could also be the result of an increase in the rate of enzyme synthesis (Roessler, 1988; Roessler et al., 1994).

Fig.1 Acetyl co-A carboxylase activity at different Si treatment (T1, T2, T3 and T4) in O. aurita and $C$. muelleri

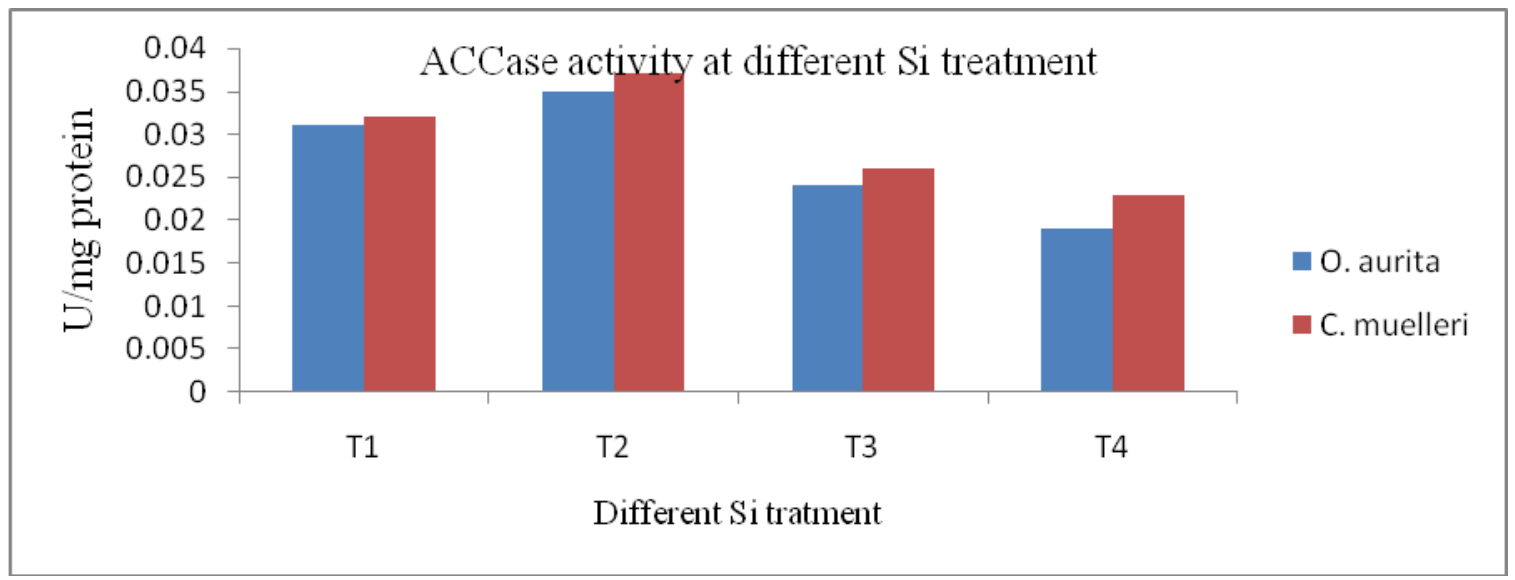


Fig.2 Acetyl co-A carboxylase activity at different acetyl co-A concentration in $O$. aurita and $C$. muelleri

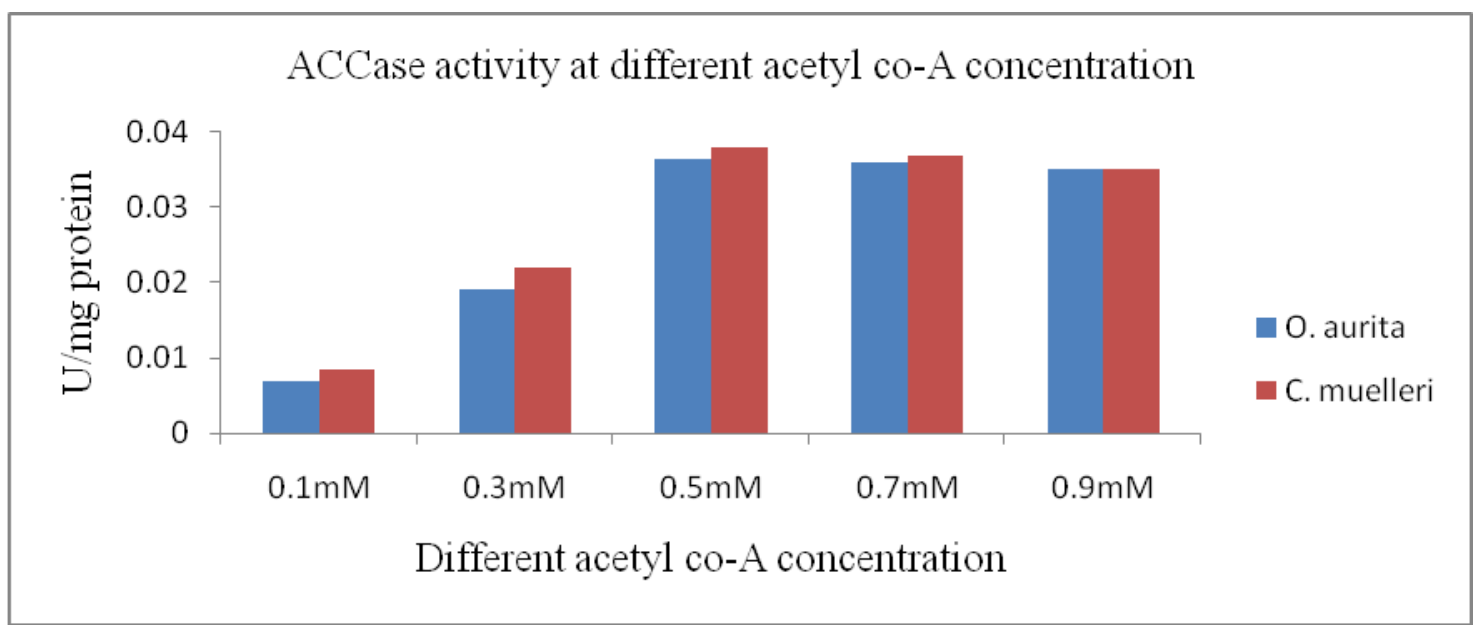

Fig.3 Acetyl co-A carboxylase activity at different $\mathrm{pH}$ in $O$. aurita and $C$. muelleri

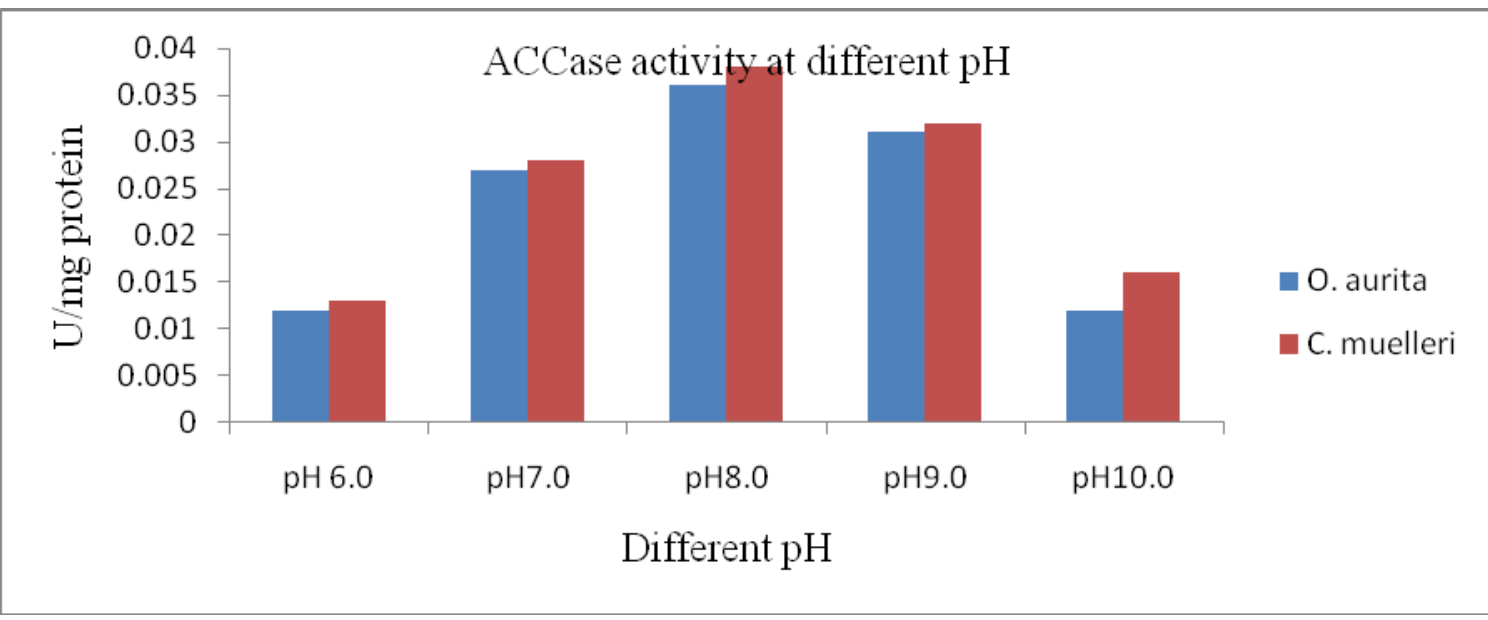

Fig.4 Acetyl co-A carboxylase activity at different temperature in $O$. aurita and $C$. muelleri

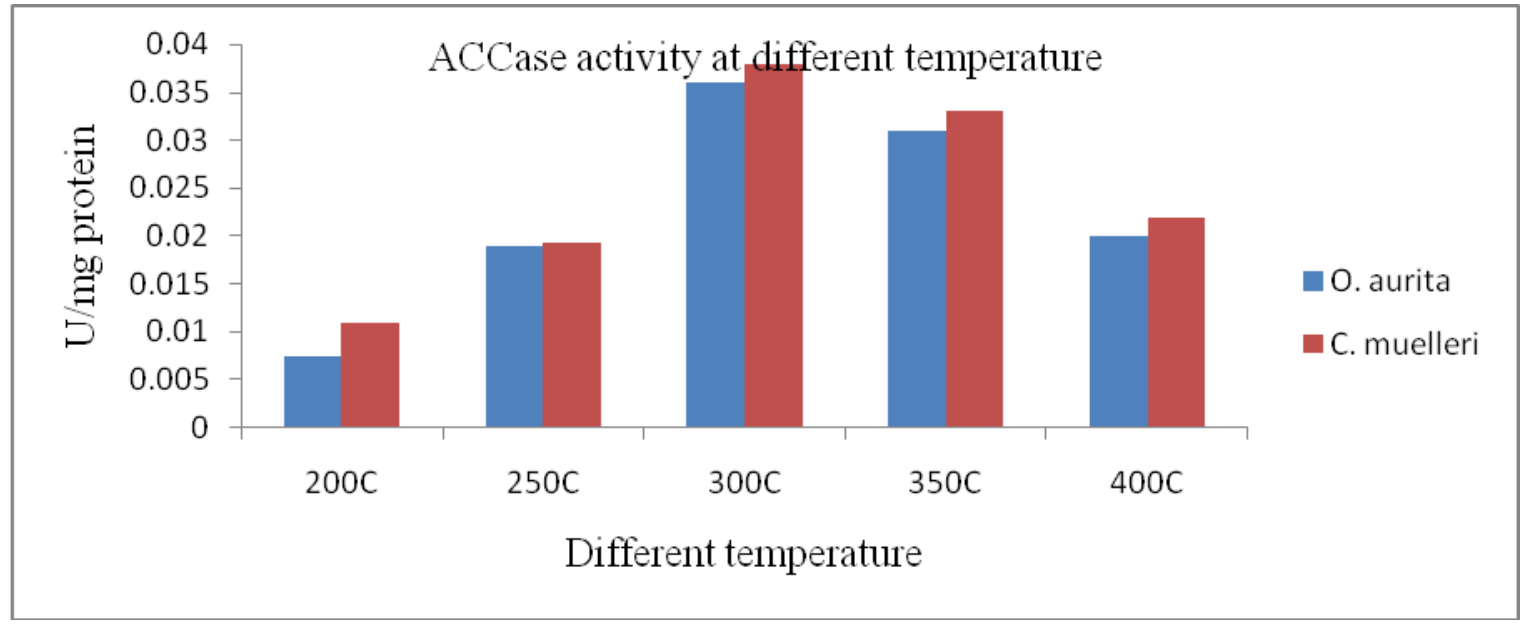


Simillarly Avidan et al., (2015) reported that $\mathrm{N}$ starvation induced dramatic variations in the level of Ac-CoA in all three species, but to varying degrees. Roessler (1990) investigated ACCase activity $0.0245 \mathrm{U} / \mathrm{mg}$ protein in crude extract of Cyclotella cryptic, present study also similar finding in treatment T3(Si $106 \mu \mathrm{M})$.

The optimum substrate (acetyl co-A) concentration for acetyl co-A carboxylase was $0.5 \mathrm{mM}$ and temperature for the in vitro activity of the enzyme was $30^{\circ} \mathrm{C}$, below and up to this temperature enzyme activity falls rapidly, result are accordance with previous report of Livne and Sukenik (1990). AcetylCoA carboxylase from $O$. aurita and $C$. muelleri had a slightly alkaline $\mathrm{pH}$ optimum ( $\mathrm{pH}$ 8.o), which is typical for acetyl- CoA carboxylases from many sources. The optimum $\mathrm{pH}$ of ACCase from the diatom Cyclotella cryptica (Roessler, 1990), spinach (Mohan and Kekwick, 1980), maize (Nikolau and Hawke, 1984) and rape seed (Slabas and Hellyer, 1985) was reported to be 8.2, 7.7, 8.4 and 8.5 respectively.

In conclusion, the results of the present investigation suggest that Acetyl co-A carboxylase activity found maximum in reduced concentration of $\mathrm{Si}$ Treatment medium (53 $\mu \mathrm{M}-\mathrm{T} 2)$ in both species of marine diatoms. $C$. muelleri $(0.037 \pm 0.006 \mathrm{U} /$ $\mathrm{mg}$ protein fresh weight) shows little higher acetyl co-A carboxylase activity than $O$. aurita $(0.035 \pm 0.006 \mathrm{U} / \mathrm{mg}$ protein fresh weight). $0.5 \mathrm{mM}$ Acetyl co-A, $\mathrm{pH} 8.0$ and temperature $30^{\circ} \mathrm{C}$ is favourable condition for Acetyl co-A carboxylase activity in marine diatoms.

\section{Acknowledgement}

Authors would like to thank the authorities of SHIATS, Allahabad and CAS in Marine Biology, Annamalai University, Parangipettai for giving me opportunity for giving necessary facility for completion of the work, author also thankful to ICAR-New Delhi for giving financial support.

Conflict of interest: We have no conflict of interest.

\section{References}

Avidan, O.B., A.I. Rogachev, and Pick, U. 2015. Enhanced acetyl-CoA production is associated with increased triglyceride accumulation in the green alga Chlorella desiccate. J. Experimental Bot., 66(13): 3725-3735.

Ahmad, A., I. Khan, Abdin, M.Z. 2000. Effect of $S$ fertilization on oil accumulation, acetyl-CoA concentration and acetyl-CoA carboxylase activity in the developing seeds of rapeseed (Brassica campestris L.). Aust. J. Agric. Res., 51: 1023-1029.

Andre, C., R.P. Haslam, Shanklin, J. 2012. Feedback regulation of plastidic acetylCoA carboxylase by 18:1-acyl carrier protein in Brassica napus. Proceedings of the National Academy of Sciences, USA 109, 10107-10112.

Ben-Amtoz, A., T.G. Tornabene, Thomas, W.H. 1985. Chemical profile of selected species of microalgae with emphasis of lipids. J. Phycol., 21: 72-81.

Dayan, F.E., K.D. Owens, N. Corniani, F.M.L. Silva, S.B.Watson, J.L. Howell, and Dale, L.S. 2015. Biochemical Markers and Enzyme Assays for Herbicide Mode of Action and Resistance Studies. Weed Sci., 23-63.

Evenson, K.J., Gronwald, J.W. and Wyse, D.L. 1994. Purif ication and Characterization of Acetyl-Coenzyme A Carboxylase from Diclofop-Resistant and Susceptible Lolium multiflorum. Plant Physiol., 105: 671-680.

Guillard, R.R.L. 1975. Culture of Phytoplankton for feeding marine 
invertebrates. Pp26-60. In: Smith, W.L., Chanley, M.H.(Eds), Culture of marine invertebrates animals. Plenum Press, New York. 338pp.

Hsieh, C.H., and Wu, W.T. 2009. Cultivation of microalgae for oil production with a cultivation strategy of urea limitation. Bioresour. Technol., 100: 39216.

Huerlimann, R., Heimann, K. 2013. Comprehensive guide to acetylcarboxylases in algae. Critical Reviews in Biotechnol., 33: 49-65.

Klaus, D., Ohlrogge, J.B., Neuhaus, H.E., Dormann, P. 2004. Increased fatty acid production in potato by engineering of acetyl-CoA carboxylase. Planta., 219: 389-396.

Lowry, O.H., Rosebrough, N.J., Farr, A.L. and Randall, R.J. 1951. Protrin measurement with the folin phenol reagent. J. Biol. Chem., 265-275.

Lardizabal, K., Effertz, R., Levering, C., Mai, J., Pedroso, M.C., Jury, T., Aasen, E., Gruys, K., Bennett, K. 2008. Expression of Umbelopsis ramanniana DGAT2A in seed increases oil in soybean. Plant Physiol., 148: 89-96.

Li, Y., Han, D., Hu, G., Dauvillee, D., Sommerfeld, M., Ball, S., Hu, Q. 2010. Chlamydomonas starchless mutant defective in ADP-glucose pyrophosphorylase hyper-accumulates triacylglycerol. Metabolic Engi., 12: 387-391.

Mock, T., Samanta, M.P., Iverson, V., Berthiaume, C., Robison, M., Holtermann, K., Durkin, C., Bondurant, S.S., Richmond, K., Rodesch, Msanne, J., Xu, D., Konda, A.R., Casas-Mollano, J.A., Awada, T., Cahoon, E.B., Cerutti, H. 2012. Metabolic and gene expression changes triggered by nitrogen deprivation in the photoautotrophically grown microalgae Chlamydomonas reinhardtii and Coccomyxa sp. C-169. Phytochem., 75: 50-59.
Mohan, N., Rajaram, M.G., Boopathy, A.B and Rengasamy, R. 2012. Biomass and lipid production of marine diatom Amphiprora paludosa W. Smith at different nutrient concentrations. $J$. Algal Biomass Utln., 3(4): 52-59.

Madoka, Y., Tomizawa, K.I., Mizoi, J., Nishida, I., Nagano, Y. and Sasaki. Y. 2002. Chloroplast transformation with modified $a c c D$ operon increases acetylCoA carboxylase and causes extension of leaf longevity and increase in seed yield in tobacco. Plant Cell Physiol., 43(12): 1518-1525.

Nikolau, B.J., Hawke, J.C. 1984. Purification and characterization of maize leaf acetyl-coenzyme A carboxylase. Arch Biochem. Biophys., 228: 86-96.

Palanisami, S., Lee, K., Nam, P.K.S. 2013. Activity of microalgal lipid accumulating key enzyme isocitrate dehydrogenase on nutrient feeding modulation. Int. J. Curr. Microbiol. App. Sci., 2(8): 389-393.

Roessler, P.G. 1988. Changes in the activities of various lipid and carbohydrate biosynthetic enzymes in the diatom Cyclotella cryptica in response to silicon deficiency. Arch. Biochem. Biophys., 267: 521-528.

Rendina, A.R., Felts, J.M., Beaudoin, J.D., Craig-Kennard, A.C., Look, L.L., Paraskos, S.L., Hagenah, J.A. 1988. Kinetic characterization, stereo selectivity, and species selectivity of the inhibition of plant acetyl- CoA carboxylase by the aryloxy phenoxypropionic acid grass herbicides. Arch. Biochem. Biophys., 265: 219-225.

Roessler, P.G. 1990. Purification and Characterization of Acetyl-CoA Carboxylase from the Diatom Cyclotella cryptical. Plant Physiol., 92: 73-78.

Slabas, A.R., Hellyer, A. 1985. Rapid purification of a high molecular weight 
subunit polypeptide form of rape seed acetyl Co-A carboxylase. Plant Sci., 39: 177-182.

Suen, Y., Hubbard, J.S., Holzer, G., Tornabene, T.G. 1987. Total lipid production of green alga Nannochlorophysis sp. Q II under different nitrogen regimes. J. Phycol., 23: 289-96.

Subhramanyan, R. 1946. A systematic account of the marine plankton diatoms of the Madras coast, Proc. Ind. Acad. Sci., 24B: 85-197.

Sasaki, Y., Nagano, Y. 2004. Plant acetylCoA carboxylase: Structure, biosynthesis, regulation, and gene manipulation for plant breeding. Biosci. Biotechnol. Biochem., 68: 1175-1184.

Tomas, C.R. 1997. Identifying marine phytoplankton. Academic press, California, USA. pp.858.

Vicente, G., Martinez, M., Aracil, J. 2004. Integrated biodiesel production: A comparison of different homogeneous catalysts systems. Bioresour. Technol., 92: 297-305.

Venkataraman, G. 1939. A systematic account of some south Indian diatoms, Proc. Ind. Acad. Sci., 10: 293-368.

Work, V.H., Radakovits, R., Jinkerson, R.E., Meuser, J.E., Elliott, L.G., Vinyard, D.J., Laurens, L.M.L., Dismukes, G.C., Posewitz, M.C. 2010. Increased lipid accumulation in the Chlamydomonas reinhardtii sta7-10 starchless isoamylase mutant and increased carbohydrate synthesis in complemented strains. Eukaryotic Cell, 9: 1251-1261.

Yu, E.T., Zendejas, F.J., Lane, P.D., Gaucher, S., Simmons, B.A. and Lane, T.W. 2009. Triacylglycerol accumulation and profiling in the model diatoms Thalassiosira pseudonana and Phaeodactylum tricornutum (Baccilariophyceae) during starvation. J. Appl. Phycol., 21: 669-681.

\section{How to cite this article:}

Shailesh Upadhyay, Kapil Lawrence, Sudhir K. Shekhar, M. Suresh and P. Anantharaman. 2017. Analysis of Acetyl Co-A Carboxylase Activity in Marine Diatoms Isolated from Vellar Estuary, Southest Coast of India. Int.J.Curr.Microbiol.App.Sci. 6(4): 1744-1752. doi: https://doi.org/10.20546/ijcmas.2017.604.209 